\title{
Elevated Blood Pressure in School Children and Adolescents - Prevalence and Associated Risk Factors
}

\author{
Vera Musil, Marjeta Majer and Vesna Jureša \\ University of Zagreb, School of Medicine, »Andrija Štampar« School of Public Health, Department of Social Medicine and \\ Organization of Health Care, Zagreb, Croatia
}

\begin{abstract}
A B S T R A C T
Elevated blood pressure (BP) in children and adolescents is determined on normative distribution of BP in healthy children. The aim of this study was to determine prevalence of high normal and elevated BP among school children and to assess associated risk factors. The study comprised 965 children (48.7\% girls) in $8^{\text {th }}$ grade of primary school. Data were obtained from questionnaire and anthropometric measurements. The prevalence of high normal BP was $28.5 \%$ in girls, 36.8\% in boys, and elevated BP 7.9\% in girls and 5.3\% in boys. Overweight was present in $19.4 \%$ of girls and $9.3 \%$ boys with high normal, and $29.7 \%$ of girls and $30.8 \%$ boys with elevated BP. Hypertension in family history was the most common associated factor reported by boys and girls with high normal and elevated BP. Follow-up of children throughout school age makes possible taking of preventative measures and promotion of healthy life style.
\end{abstract}

Key words: children, adolescent, blood pressure, risk factors, school health service

\section{Introduction}

Hypertension is a progressive cardiovascular syndrome arising from complex and interrelated aetiology ${ }^{1}$. It is important worldwide public-health challenge, not only because of its high frequency, but also because it is only one of several proven major modifiable risk factors for cardiovascular disease ${ }^{2}$. Analysis indicates that more than a quarter of the world's adult population has hypertension and that this proportion will increase to $29 \%$ by $2025^{3}$, and causes $6 \%$ of deaths each year that occur worldwide ${ }^{4}$. Recent study in Croatia has shown a prevalence of hypertension of $40.5 \%$ for men and $34.9 \%$ for women ${ }^{5}$. The prevalence of hypertension among school children and youth has been reported by ranges from $11.4 \%$ to $19.4 \%$ after first, $3.8 \%$ to $9.5 \%$ after second and from $2.2 \%$ to $4.5 \%$ after third screening ${ }^{6,7}$. Elevated blood pressure in children and adolescents is determined on the normative distribution of blood pressure (BP) in healthy children. Hypertension is defined as average systolic blood pressure (SBP) and/or diastolic blood pressure (DBP) that is $\geq 95^{\text {th }}$ percentile for gender, age and height on three separate occasions. SBP or DBP values that are $\geq 90^{\text {th }}$ percentile but $<95^{\text {th }}$ percentile are designated as "high normal « and are considered to be an indication of heightened risk for developing hypertension. It is now recommended, that as with adults, children and adolescents with BP levels $\geq 120 / 80 \mathrm{~mm} \mathrm{Hg}$ but $<95$ th percentile should be considered pre-hypertensive ${ }^{8,9}$. Large scale epidemiology studies have shown that essential hypertension could be found among children and adolescents. Persistence (tracking) of BP trough childhood and from childhood into adulthood showed that adult BP is correlated with childhood BP, body size and change in ponderosity from childhood to adult life. An elevated BP, obesity and positive family history of hypertension in childhood are likely to help predict adult hypertension ${ }^{10-14}$. Studies of this type, not only help understand when and how adult hypertension occurs, but also have implications for early detection and prevention of the development of hypertension by appropriate dietary and life-style modifications starting in childhood ${ }^{8}$. Examinations of trends in SBP and DBP among children and adolescents (aged from 8 to 17 years) between 1988 and 2000 showed that SBP and DBP have increased. Except an increase in body mass index (BMI), for at least part of the increase in BP

Received for publication September 1, 2011 
are responsible additional factors that still should be identified $^{15}$. The pre-hypertension or high normal BP category is created to target children at risk for early identification and intervention. No outcome data exist to support the risk associated with pre-hypertension among adolescents as it is currently defined. Examination of the progression from pre-hypertension to hypertension are required regarding its time course and other associated abnormalities ${ }^{8,16,17}$. BP screening test in children and adolescents is necessary in order to allow early identification of children at risk and to start taking the necessary precautions to prevent and/or control the development of hypertension $^{18}$.

The aim of this study was to determine prevalence of high normal and elevated blood pressure among healthy school children and to assess personal medical history, family history and overweight as associated risks.

\section{Materials and Methods}

The present study included 965 school children $(48.7 \%$ girls) in $8^{\text {th }}$ grade of primary school. Data for this study was obtained from a previous study The School Health Survey 2003-2004 involving children from representative sample of 40 primary and 20 secondary schools. The Survey was conducted in children in $1^{\text {st }}$ and $8^{\text {th }}$ grade of primary and $3^{\text {rd }}$ grade of secondary school. The methodology of The School Health Survey was described in the special paper ${ }^{19}$ and in the latest issue of the journal ${ }^{20,21}$. In total, 3,101 individuals were selected to participate in The School Health Survey 2003-2004. Out of these selected individuals, response was obtained for 2,851 individuals which results in an overall response rate of $91.9 \%$. Questionnaires were administered to all students in classroom and 30 minutes were given to fulfil. Children in $8^{\text {th }}$ grade of primary and $3^{\text {rd }}$ grade of secondary schools answered the questionnaires by themselves and questionnaires were collected immediately by team of examiners.

Questionnaire The School Health Survey 2003-2004 consisted of following group of questions about: family structure (education of parents, employment status, occupation, number of children in family, order of birth); socio economic, demographic characteristics of selected respondent (age, gender, place of birth, place where live); dietary habits (number of meals, breakfast, fat and caffeine intake, meat, fruit and vegetable consumption); physical activity (time spent and endurance); television and computer use (time spent) - only for $1^{\text {st }}$ grade of primary school; alcohol (consumption, binge drinking); drug abuse (consumption) - only for $8^{\text {th }}$ grade of primary and $3^{\text {rd }}$ grade of secondary school; smoking (smoking habits); teeth hygiene; traffic safety (driving, using of seatbelt); physical conflicts (violence and bullying); self reported health problems (headaches, stomach or back pain and other diseases); family medical history (health problems of family members).

Anthropometric measurements (body height, body weight, blood pressure, heart rate) were taken approximately 5-7 minutes per one student, by trained team of examiners. Children were measured wearing light clothes and no shoes in calm, quite and comfortable setting. Body weight was measured on calibrated digital scale (Seca 862 ) and recorded to nearest 100 grams and body height was measured by a fixed wall-mounted stadiometer and recorded to nearest 0.1 centimetres. Blood pressure measurements were taken during one visit to the schools. BP was measured after the child rested 10 minutes in a comfortable sitting position. None of the children were agitated and none of them had pain. BP was measured twice by auscultation using a standard sphygmomanometer (Riester) with a time interval of at least 30 seconds between the two measurements, on the right upper arm, bent 90 degrees at the elbow, with appropriate cuffs size and recorded to nearest 2 millimetres. Phase I Korotkoff sound was used to indicate SPB and Phase V for DBP. Between two measures, the heart rate was measured in 30 seconds.

Girls were directly asked whether they started to menstruate, and if yes, the exact month and year were recorded.

Data for this study were obtained from completion of questionnaire and physical examination. For the purpose of this study, we analyzed answers from questionnaire about personal medical history (»Have you in the past three years visit a physician for difficulties with: heart and cardiovascular system or/ and thyroid gland? «) and family medical history: (»Illnesses in the family - father, mother, brothers, sisters, grandmothers and grandfathers: elevated blood pressure, heart diseases, diseases of thyroid gland, increased level of blood lipids, diabetes «). On the basis of the data obtained by measurements, BMI as weight $/$ height $^{2}\left(\mathrm{~kg} / \mathrm{m}^{2}\right)$ and average value of two BP measurements for SPB and DBP were calculated. In order to calculate the prevalence of high normal and elevated $B P$ the mean value of two blood pressure measurements for SPB and DBP were used in analysis. Boys and girls with a $B M I \geq 90^{\text {th }}$ percentile for sex and age were considered as being overweight. Overweight (BMI $\geq 90^{\text {th }}$ percentile) and obese (BMI $\geq 95^{\text {th }}$ percentile) categories were combined and described as overweight in this paper. The evaluation of BMI was performed according to Croatian BMI referent values for children aged 6.5-18.5 years ${ }^{22}$. Boys and girls with mean value of SBP and/or $\mathrm{DBP} \geq 95^{\text {th }}$ percentile for sex and age were considered to have elevated BP according to Croatian BP referent values for children aged 6.5-18.5 years ${ }^{22}$. Boys and girls were considered to have high normal BP if mean value of SBP and/or DBP was $\geq 120 / 80 \mathrm{mmHg}^{8,9}$ or if average value of SBP and/or DBP level was $\geq 90^{\text {th }}$ percentile but $<95$ th percentile for sex and age according to Croatian BP referent values for children aged 6.5-18.5 years ${ }^{22}$. Boys and girls were divided in three categories according to BP level: normal BP, high normal BP and elevated BP. Rates of normal, high normal and elevated BP were calculated. Rates of overweight, positive personal and family medical history were calculated for those categories.

Descriptive statistics was used to describe the distributions of variables and $\chi^{2}$-test was used to test the dif- 
TABLE 1

THE DISTRIBUTION OF CHILDREN ACCORDING TO BLOOD PRESSURE CATEGORIES

\begin{tabular}{lcccc}
\hline & \multicolumn{3}{c}{ Blood pressure categories } & \\
\cline { 2 - 4 } & $\begin{array}{c}\text { Normal } \\
\text { BP }\end{array}$ & $\begin{array}{c}\text { High-normal } \\
\text { BP }\end{array}$ & $\begin{array}{c}\text { Elevated } \\
\text { BP }\end{array}$ & Total \\
\cline { 2 - 4 } & $\mathrm{N}(\%)$ & $\mathrm{N}(\%)$ & $\mathrm{N}(\%)$ & $\mathrm{N}(\%)$ \\
\hline Girls & $* 299(63.6)$ & $* 134(28.5)$ & $* 37(7.9)$ & $470(100.0)$ \\
Boys & $* 287(58.0)$ & $* 182(36.8)$ & $* 26(5.3)$ & $495(100.0)$ \\
Total & $586(60.7)$ & $316(32.7)$ & $63(6.5)$ & $965(100.0)$ \\
\hline
\end{tabular}

${ }^{*} \chi^{2}=8.816, \mathrm{p}=0.0122, \mathrm{BP}-$ blood pressure

ference between the groups according BP categories. Statistical significance was defined as $\mathrm{p}<0.05$. The Statistica 9.0 was used for data analysis.

\section{Results}

The present study included 956 children in $8^{\text {th }}$ grade of primary school, 470 girls (average age 14.66) and 495 boys (average age 14.73 years). The prevalence of high normal BP was $32.7 \%, 28.5 \%$ in girls and $36.8 \%$ in boys. The prevalence of elevated BP was $6.5 \%, 7.9 \%$ in girls and $5.3 \%$ in boys (Table 1). The prevalence of elevated SBP was $1.9 \%, 1.9 \%$ in girls and $1.8 \%$ in boys. The prevalence of elevated DBP was $3.3 \%, 4.3 \%$ in girls and $2.4 \%$ in boys. Elevated SBP and DBP had $1.3 \%$ children, $1.7 \%$ of girls and $1.0 \%$ of boys. The prevalence rate of high normal BP was higher in boys and elevated BP in girls. The difference was statistically significant $(p=0.0122)$. Average values of SBP, DBP and BMI have increased in boys and girls from group with normal, high normal to elevated BP. Average values of SBP and DBP in groups with normal, high normal and elevated $\mathrm{BP}$ were higher in boys than in girls. Average BMI was higher in girls, except boys with elevated BP (Table 2). Cardiovascular risk (CVR) factors associated to high normal and elevated BP were analyzed separately for boys and girls. In personal medical history, more boys and girls with high normal and elevated BP reported difficulties with heart and cir- culatory system than those with normal BP. Problems with thyroid gland were reported by $13.5 \%$ of girls with elevated BP and $1.5 \%$ of those with high normal and $2.3 \%$ with normal BP, with statistically significant difference $(p<0.001)$. In boys, problem with thyroid gland was present in category of normal BP $0.7 \%$ and high normal $1.1 \%$ but not in group with elevated BP. The rate of overweight was higher in boys and girls with high normal and elevated BP than in those with normal BP. Of girls, 3.7 with normal, 19.4 high normal and $29.7 \%$ with elevated $\mathrm{BP}$ were considered to be overweight. Of boys, 2.4 with normal, 9.3 with high normal and $30.8 \%$ with elevated $\mathrm{BP}$ were overweight (Table 3). In family medical history, hypertension was reported by $44.5 \%$ girls with normal, 43.3\% high normal and $51.4 \%$ with elevated BP. The prevalence in boys considering BP categories was 34.1, 35.2 and $42.3 \%$, respectively. Heart disease was reported by $24.4 \%$ girls with normal, $20.9 \%$ high normal and $18.9 \%$ with elevated BP. The rates in boys were $20.6,14.8$ and $23.1 \%$, respectively. Thyroid gland disease was more common in girls with normal $15.1 \%$ and elevated BP $21.6 \%$ than in group with high normal BP 6.7\%. The difference was statistically significant $(p=0.015)$. Increased level of blood lipids was present in $27.1 \%$ girls with normal. 21.6 with high normal and $32.4 \%$ with elevated BP. In boys, the rates were $14.3,18.7$ and $15.4 \%$ respectively. Diabetes was present in $22.7 \%$ girls with normal, $27.6 \%$ high normal and $18.9 \%$ with elevated BP. The rates in boys were 19.2, 21.4 and $23.1 \%$ (Table 4 ). Considering personal medical history, family history and overweight as associated CVR factors to high normal and elevated BP, without those associated risks were $41.2 \%$ boys and $24.6 \%$ girls with high normal BP and $26.9 \%$ of boys and $21.6 \%$ of girls with elevated BP (Table 5). Two or more additional CVR factors were more frequent in girls with high normal $17.9 \%$ and elevated BP $32.4 \%$ than in those with normal BP $6.0 \%$, with statistically significant difference $(p<0.001)$. In boys, the prevalence of two or more associated CVR factors were $4.2 \%$ in group with normal, 9.9\% high normal and $19.2 \%$ with elevated BP, with statistically significant difference $(p=0.0127)$ (Table 6). Considering prevalence rate of observed associated CVR factors, the most common CVR factor in boys and girls in all three BP categories was hypertension in family history.

TABLE 2

MEAN VALUE OF SYSTOLIC, DIASTOLIC BLOOD PRESSURE AND BODY MASS INDEX IN BOYS AND GIRLS ACCORDING TO BLOOD PRESSURE CATEGORIES

\begin{tabular}{|c|c|c|c|c|c|c|}
\hline & \multicolumn{6}{|c|}{ Blood pressure categories } \\
\hline & \multicolumn{2}{|c|}{ Normal BP } & \multicolumn{2}{|c|}{ High-normal BP } & \multicolumn{2}{|c|}{ Elevated BP } \\
\hline & $\begin{array}{c}\text { Girls } \\
\overline{\mathrm{X}} \pm \mathrm{SD}\end{array}$ & $\frac{\text { Boys }}{\overline{\mathrm{X}} \pm \mathrm{SD}}$ & $\begin{array}{c}\text { Girls } \\
\overline{\mathrm{X}} \pm \mathrm{SD}\end{array}$ & $\begin{array}{c}\text { Boys } \\
\overline{\mathrm{X}} \pm \mathrm{SD}\end{array}$ & $\begin{array}{c}\text { Girls } \\
\overline{\mathrm{X}} \pm \mathrm{SD}\end{array}$ & $\begin{array}{c}\text { Boys } \\
\overline{\mathrm{X}} \pm \mathrm{SD}\end{array}$ \\
\hline Systolic blood pressure (mmHg) & $107.16 \pm 8.27$ & $108.71 \pm 7.91$ & $123.53 \pm 5.85$ & $125.30 \pm 6.47$ & $134.03 \pm 12.21$ & $142.52 \pm 15.11$ \\
\hline Diastolic blood pressure (mmHg) & $62.92 \pm 7.72$ & $63.71 \pm 7.53$ & $74.71 \pm 6.80$ & $73.76 \pm 8.73$ & $83.97 \pm 7.38$ & $89.10 \pm 11.94$ \\
\hline Body mass index $\mathrm{kg} / \mathrm{m}^{2}$ & $19.91 \pm 2.64$ & $19.52 \pm 2.72$ & $21.63 \pm 4.20$ & $21.30 \pm 3.86$ & $22.87 \pm 4.48$ & $23.19 \pm 4.34$ \\
\hline
\end{tabular}

$\overline{\mathrm{X}}$ - Mean, SD - standard deviation, BP - blood pressure 
TABLE 3

THE DISTRIBUTION OF CARDIOVASCULAR RISKS ACCORDING TO BLOOD PRESSURE CATEGORIES

\begin{tabular}{lcccccc}
\hline & \multicolumn{5}{c}{ Blood pressure categories } \\
\cline { 2 - 7 } Cardiovascular risks & \multicolumn{2}{c}{ Normal BP } & High-normal BP & \multicolumn{2}{c}{ Elevated BP } \\
\cline { 2 - 7 } & $\begin{array}{c}\text { Girls } \\
(299)\end{array}$ & $\begin{array}{c}\text { Boys } \\
(287)\end{array}$ & $\begin{array}{c}\text { Girls } \\
(134)\end{array}$ & $\begin{array}{c}\text { Boys } \\
(182)\end{array}$ & $\begin{array}{c}\text { Girls } \\
(37)\end{array}$ & $\begin{array}{c}\text { Boys } \\
(26)\end{array}$ \\
\cline { 2 - 7 } & $\mathrm{N}(\%)$ & $\mathrm{N}(\%)$ & $\mathrm{N}(\%)$ & $\mathrm{N}(\%)$ & $\mathrm{N}(\%)$ & $\mathrm{N}(\%)$ \\
\hline $\begin{array}{l}\text { Personal medical history: heart } \\
\text { and circulatory system diseases }\end{array}$ & $9(3.0)$ & $10(3.5)$ & $5(3.7)$ & $7(3.8)$ & $2(5.4)$ & $1(3.8)$ \\
$\begin{array}{l}\text { Personal medical history: } \\
\text { thyroid gland diseases } \\
\text { Overweight }\end{array}$ & $* 7(2.3)$ & $2(0.7)$ & $* 2(1.5)$ & $2(1.1)$ & $* 5(13.5)$ & $0(0.0)$ \\
\hline
\end{tabular}

$* \chi^{2}=15.653, \mathrm{p}=0,000, \mathrm{BP}-$ blood pressure

TABLE 4

THE DISTRIBUTION OF CARDIOVASCULAR RISKS IN FAMILY HISTORY ACCORDING TO BLOOD PRESSURE CATEGORIES

\begin{tabular}{lcccccc}
\hline & \multicolumn{3}{c}{ Blood pressure categories } \\
\cline { 2 - 7 } Cardiovascular risks & \multicolumn{2}{c}{ Normal BP } & \multicolumn{2}{c}{ High-normal BP } & \multicolumn{2}{c}{ Elevated BP } \\
\cline { 2 - 7 } in family history & $\begin{array}{c}\text { Girls } \\
(299)\end{array}$ & $\begin{array}{c}\text { Boys } \\
(287)\end{array}$ & $\begin{array}{c}\text { Girls } \\
(134)\end{array}$ & $\begin{array}{c}\text { Boys } \\
(182)\end{array}$ & $\begin{array}{c}\text { Girls } \\
(37)\end{array}$ & $\begin{array}{c}\text { Boys } \\
(26)\end{array}$ \\
\cline { 2 - 7 } & $\mathrm{N}(\%)$ & $\mathrm{N}(\%)$ & $\mathrm{N}(\%)$ & $\mathrm{N}(\%)$ & $\mathrm{N}(\%)$ & $\mathrm{N}(\%)$ \\
\hline Hypertension & $133(44.5)$ & $98(34.1)$ & $58(43.3)$ & $64(35.2)$ & $19(51.4)$ & $11(42.3)$ \\
Heart disease & $73(24.4)$ & $59(20.6)$ & $28(20.9)$ & $27(14.8)$ & $7(18.9)$ & $6(23.1)$ \\
Thyroid gland disease & $* 45(15.1)$ & $25(8.7)$ & $* 9(6.7)$ & $1(0.5)$ & $* 8(21.6)$ & $1(3.8)$ \\
Increased level of blood lipids & $81(27.1)$ & $41(14.3)$ & $29(21.6)$ & $34(18.7)$ & $12(32.4)$ & $4(15.4)$ \\
Diabetes & $68(22.7)$ & $55(19.2)$ & $37(27.6)$ & $39(21.4)$ & $7(18.9)$ & $6(23.1)$ \\
\hline
\end{tabular}

${ }^{*} \chi^{2}=8.387, \mathrm{p}=0,015, \mathrm{BP}-$ blood pressure

TABLE 5

PRESENCE OF ASSOCIATED CARDIOVASCULAR RISKS ACCORDING TO BLOOD PRESSURE CATEGORIES

\begin{tabular}{lcccccc}
\hline & \multicolumn{3}{c}{ Blood pressure categories } \\
\cline { 2 - 7 } & \multicolumn{2}{c}{ Normal BP } & \multicolumn{2}{c}{ High-normal BP } & \multicolumn{2}{c}{ Elevated BP } \\
\cline { 2 - 7 } Cardiovascular risks & Girls & Boys & Girls & Boys & Girls & Boys \\
& $(299)$ & $(287)$ & $(134)$ & $(182)$ & $(37)$ & $(26)$ \\
\cline { 2 - 7 } & $\mathrm{N}(\%)$ & $\mathrm{N}(\%)$ & $\mathrm{N}(\%)$ & $\mathrm{N}(\%)$ & $\mathrm{N}(\%)$ & $\mathrm{N}(\%)$ \\
\hline Without associated cardiovascular & 74 & 122 & 33 & 75 & 8 & 7 \\
risks & $(24.7)$ & $(42.5)$ & $(24.6)$ & $(41.2)$ & $(21.6)$ & $(26.9)$ \\
Personal medical history or family & 207 & 153 & 77 & 89 & 17 & 14 \\
medical history or overweight & $(69.2)$ & $(53.3)$ & $(57.5)$ & $(48.9)$ & $(45.9)$ & $(53.8)$ \\
Personal medical history and family & 10 & 6 & 4 & 2 & 3 & 1 \\
medical history & $(3.3)$ & $(2.1)$ & $(3.0)$ & $(1.1)$ & $(8.1)$ & $(3.8)$ \\
Personal medical history and & 0 & 0 & 0 & 0 & 0 & 0 \\
overweight & $(0.0)$ & $(0.0)$ & $(0.0)$ & $(0.0)$ & $(0.0)$ & $(0.0)$ \\
Family medical history and & 8 & 6 & 19 & 16 & 7 & 4 \\
overweight & $(2.7)$ & $(2.1)$ & $(14.2)$ & $(8.8)$ & $(18.9)$ & $(15.4)$ \\
Personal medical history and family & 0 & 0 & 1 & 0 & 2 & 0 \\
medical history and overweight & $(0.0)$ & $(0.0)$ & $(0.7)$ & $(0.0)$ & $(5.4)$ & $(0.0)$ \\
\hline Total & $299(100.0)$ & $287(100.0)$ & $134(100.0)$ & $182(100.0)$ & $37(100.0)$ & $26(100.0)$ \\
\hline
\end{tabular}

BP - blood pressure 
TABLE 6

NUMBER OF ASSOCIATED CARDIOVASCULAR RISKS ACCORDING TO BLOOD PRESSURE CATEGORIES

\begin{tabular}{|c|c|c|c|c|c|c|}
\hline \multirow{4}{*}{$\begin{array}{l}\text { Number of } \\
\text { cardiovascular } \\
\text { risks }\end{array}$} & \multicolumn{6}{|c|}{ Blood pressure categories } \\
\hline & \multicolumn{2}{|c|}{ Normal BP } & \multicolumn{2}{|c|}{ High-normal BP } & \multicolumn{2}{|c|}{ Elevated BP } \\
\hline & $\begin{array}{l}\text { Girls } \\
(299)\end{array}$ & $\begin{array}{l}\text { Boys } \\
(287)\end{array}$ & $\begin{array}{l}\text { Girls } \\
(134)\end{array}$ & $\begin{array}{l}\text { Boys } \\
(182)\end{array}$ & $\begin{array}{c}\text { Girls } \\
(37)\end{array}$ & $\begin{array}{l}\text { Boys } \\
(26)\end{array}$ \\
\hline & $\mathrm{N}(\%)$ & $\mathrm{N}(\%)$ & $\mathrm{N}(\%)$ & $\mathrm{N}(\%)$ & $\mathrm{N}(\%)$ & $\mathrm{N}(\%)$ \\
\hline 0 & $* 74(24.7)$ & $* * 122(42.5)$ & $* 33(24.6)$ & $* * 75(41.2)$ & $* 8(21.6)$ & $* * 7(26.9)$ \\
\hline 1 & $* 207(69.2)$ & **153 (53.3) & $* 77(57.5)$ & $* * 89(48.9)$ & $* 17$ (45.9) & $* * 14(53.8)$ \\
\hline$\geq 2$ or more & $* 18(6.0)$ & $* * 12(4.2)$ & $* 24(17.9)$ & $* * 18(9.9)$ & *12 (32.4) & $* * 5(19.2)$ \\
\hline Total & $299(100.0)$ & $287(100.0)$ & $134(100.0)$ & $182(100.0)$ & $37(100.0)$ & $26(100.0)$ \\
\hline
\end{tabular}

${ }^{*} \chi^{2}=30.906, \mathrm{p}<0.001, * * \chi^{2}=12.720, \mathrm{p}=0.0127, \mathrm{BP}-$ blood pressure

In girls with normal BP, hypertension in family history was followed by increased level of blood lipids, heart disease, diabetes and thyroid gland disease. In girls with high normal BP, hypertension in family history was followed by diabetes, increased level of blood lipids, heart disease in family history and overweight. In girls with elevated BP, hypertension in family history was followed by increased level of blood lipids in family history, overweight, thyroid gland disease and diabetes in family history. In boys with normal BP, hypertension in family history was followed by heart disease, diabetes, increased level of blood lipids and thyroid gland disease in family history. In boys with high normal BP, hypertension in family history was followed by diabetes, increased level of blood lipids, heart disease in family history and overweight. In boys with elevated BP, hypertension in family history was followed by overweight, heart disease, increased level of blood lipids and thyroid gland disease in family history (Table 7).

\section{Discussion and Conclusion}

Epidemiological studies have demonstrated the importance of measuring BP during childhood and adolescence ${ }^{10-14}$. According to Task Force recommendation

TABLE 7

RANKS OF ASSOCIATED CARDIOVASCULAR RISKS ACCORDING TO BLOOD PRESSURE CATEGORIES IN BOYS AND GIRLS

\begin{tabular}{|c|c|c|c|c|c|c|c|c|c|c|c|c|}
\hline \multirow{4}{*}{ Cardiovascular risks } & \multicolumn{12}{|c|}{ Blood pressure categories } \\
\hline & \multicolumn{4}{|c|}{ Normal BP } & \multicolumn{4}{|c|}{ High-normal BP } & \multicolumn{4}{|c|}{ Elevated BP } \\
\hline & \multicolumn{2}{|c|}{$\begin{array}{l}\text { Girls } \\
(299)\end{array}$} & \multicolumn{2}{|c|}{$\begin{array}{l}\text { Boys } \\
(287)\end{array}$} & \multicolumn{2}{|c|}{$\begin{array}{l}\text { Girls } \\
(134)\end{array}$} & \multicolumn{2}{|c|}{$\begin{array}{l}\text { Boys } \\
(182)\end{array}$} & \multicolumn{2}{|c|}{$\begin{array}{c}\text { Girls } \\
(37)\end{array}$} & \multicolumn{2}{|c|}{$\begin{array}{l}\text { Boys } \\
(26)\end{array}$} \\
\hline & $\begin{array}{l}\mathrm{N} \\
(\%)\end{array}$ & Rank & $\begin{array}{l}\mathrm{N} \\
(\%)\end{array}$ & Rank & $\begin{array}{l}\mathrm{N} \\
(\%)\end{array}$ & Rank & $\begin{array}{l}\mathrm{N} \\
(\%)\end{array}$ & Rank & $\begin{array}{l}\mathrm{N} \\
(\%)\end{array}$ & Rank & $\begin{array}{l}\mathrm{N} \\
(\%)\end{array}$ & Rank \\
\hline Hypertension in family history & $\begin{array}{l}134 \\
(44.8)\end{array}$ & I & $\begin{array}{c}98 \\
(34.1)\end{array}$ & I & $\begin{array}{c}58 \\
(43.3)\end{array}$ & I & $\begin{array}{c}64 \\
(35.2)\end{array}$ & $\mathrm{I}$ & $\begin{array}{c}19 \\
(51.4)\end{array}$ & I & $\begin{array}{c}11 \\
(42.3)\end{array}$ & I \\
\hline $\begin{array}{l}\text { Increased level of blood lipids in } \\
\text { family history }\end{array}$ & $\begin{array}{c}81 \\
(27.1)\end{array}$ & II & $\begin{array}{c}41 \\
(14.3)\end{array}$ & IV & $\begin{array}{c}29 \\
(21.6)\end{array}$ & III & $\begin{array}{c}34 \\
(18.7)\end{array}$ & III & $\begin{array}{c}12 \\
(32.4)\end{array}$ & II & $\begin{array}{c}4 \\
(15.4)\end{array}$ & IV \\
\hline Heart disease in family history & $\begin{array}{c}73 \\
(24.4)\end{array}$ & III & $\begin{array}{c}59 \\
(20.6)\end{array}$ & II & $\begin{array}{c}28 \\
(20.9)\end{array}$ & IV & $\begin{array}{c}27 \\
(14.8)\end{array}$ & IV & $\begin{array}{c}7 \\
(18.9)\end{array}$ & $\mathrm{V}$ & $\begin{array}{c}6 \\
(23.1)\end{array}$ & III \\
\hline Diabetes in family history & $\begin{array}{c}68 \\
(22.7)\end{array}$ & IV & $\begin{array}{c}55 \\
(19.2)\end{array}$ & III & $\begin{array}{c}37 \\
(27.6)\end{array}$ & II & $\begin{array}{c}39 \\
(21.4)\end{array}$ & II & $\begin{array}{c}7 \\
(18.9)\end{array}$ & $\mathrm{V}$ & $\begin{array}{c}6 \\
(23.1)\end{array}$ & III \\
\hline $\begin{array}{l}\text { Thyroid gland disease in family } \\
\text { history }\end{array}$ & $\begin{array}{c}45 \\
(15.1)\end{array}$ & $\mathrm{V}$ & $\begin{array}{c}25 \\
(8.7)\end{array}$ & $\mathrm{V}$ & $\begin{array}{c}29 \\
(21.6)\end{array}$ & III & $\begin{array}{c}11 \\
(6.0)\end{array}$ & VI & $\begin{array}{c}8 \\
(21.6)\end{array}$ & IV & $\begin{array}{c}1 \\
(3.8)\end{array}$ & $\mathrm{V}$ \\
\hline Overweight & $\begin{array}{l}11 \\
(3.7)\end{array}$ & VI & $\begin{array}{c}7 \\
(2.4)\end{array}$ & VII & $\begin{array}{c}26 \\
(19.4)\end{array}$ & $\mathrm{V}$ & $\begin{array}{c}21 \\
(11.5)\end{array}$ & $\mathrm{V}$ & $\begin{array}{c}11 \\
(29.7)\end{array}$ & III & $\begin{array}{c}8 \\
(30.8)\end{array}$ & II \\
\hline $\begin{array}{l}\text { Heart and cardiovascular system } \\
\text { disease }\end{array}$ & $\begin{array}{c}9 \\
(3.0)\end{array}$ & VII & $\begin{array}{c}10 \\
(3.5)\end{array}$ & VI & $\begin{array}{c}5 \\
(3.7)\end{array}$ & VI & $\begin{array}{c}7 \\
(3.8)\end{array}$ & VII & $\begin{array}{c}2 \\
(5.4)\end{array}$ & VII & $\begin{array}{c}1 \\
(3.8)\end{array}$ & $\mathrm{V}$ \\
\hline Thyroid gland disease & $\begin{array}{c}7 \\
(2.3) \\
\end{array}$ & VIII & $\begin{array}{c}2 \\
(0.7)\end{array}$ & VIII & $\begin{array}{c}2 \\
(1.5)\end{array}$ & VII & $\begin{array}{c}2 \\
(1.1) \\
\end{array}$ & VIII & $\begin{array}{c}5 \\
(13.5) \\
\end{array}$ & VI & $\begin{array}{c}0 \\
(0.0) \\
\end{array}$ & VI \\
\hline
\end{tabular}

$\mathrm{BP}$ - blood pressure 
multiple BP measurements (at least in three separate occasions) should be obtained before making a diagnosis of pre-hypertension or hypertension. The prevalence of high normal and elevated BP is higher after an initial set of measurements ${ }^{8}$. Some authors suggest that to be classified as having pre-hypertension it is only necessary to have a BP in pre-hypertensive range at one measurement ${ }^{17}$. According to results of study performed by Brady et al. among children aged 3 to 20 years, out of $39 \%$ of children with BP level above adult values $(120 / 80 \mathrm{mmHg})$, $87 \%$ were not recognized as »at risk «. Obesity, family history of cardiovascular disease, or BPs significantly elevated above adult values was not sufficient for health care providers to recognize BP elevation in children ${ }^{23}$. Using the Croatian BP referent values according to age and sex to determine high normal and elevated BP in children of $8^{\text {th }}$ grade of primary school, the prevalence of high normal and elevated BP after first screening in our study was $32.7 \%$ and $6.5 \%$, respectively. The prevalence of high normal BP was higher in boys $36.8 \%$, than in girls $28.5 \%$, though the prevalence of elevated BP was higher among girls $7.9 \%$ than in boys $5.3 \%$. The prevalence of elevated SBP $1.9 \%$ was higher than DBP $1.3 \%$. The prevalence of elevated SBP, elevated DBP and both was higher in girls $(1.9 \%, 4.3 \%$, and $1.7 \%$ respectively) than in boys $(1.8 \%, 2.4 \%$, and $1.0 \%$ respectively). Among all children with elevated BP, the prevalence of elevated DBP $50.8 \%$ was higher than that of SBP $28.6 \%$. Using the Croatian referent values to determine overweight, the prevalence of overweight ( $\geq 90^{\text {th }}$ percentile) was $8.7 \%$, in girls $10.2 \%$ and $7.3 \%$ in boys. The prevalence of overweight was higher among boys and girls in high normal and elevated BP category, than in those with normal BP. Studies conducted in different regions among children and adolescents demonstrated different prevalence rates of overweight, obesity, high normal and elevated BP. The divergent prevalence rates of high normal and elevated BP among children and adolescents in different age groups may result from influence of methodologies, protocols, number of measurements and criteria used to determine overweight, obesity high normal and elevated BP. Akgun et al. used national percentile curves according to age and sex to determine overweight, high normal and hypertensive BP values in 7-16 years old children, using mean value of six measurements. In their study, hypertension was more common in boys than in girls and among hypertensive children, the prevalence of systolic hypertension was higher than diastolic. The rate of obesity in girls with hypertension was $10.5 \%$, in boys $13.2 \%$. In 14 years old girls, the prevalence of systolic hypertension was $5.8 \%$ and diastolic $0.9 \%$. In boys, the rates were $4.6 \%$ and $0.9 \%$, respectively. Average value of SBP and DBP were higher in boys than in girls ${ }^{24}$. Adrogué et al. found prevalence of systolic hypertension $2.7 \%$ and diastolic $2.0 \%$ in children aged 10-15 years after the initial screening. There was no significant difference in prevalence of systolic hypertension between girls $2.8 \%$ and boys $2.7 \%$ but there were a significantly greater number of girls $2.7 \%$ than boys $1.3 \%$ with diastolic hypertension, as we found in our study ${ }^{25}$. McNiece et al. have found among adoles- cents aged from 11 to 17 years prevalence of high normal blood pressure after first screening $9.5 \%$, which rose after 3 screenings to $15.7 \%$, using the same criteria as we in our study for high normal BP (BP values equals or greater than 120/80 mmHg). Prevalence of hypertension after first screening was $11.7 \%$. Overweight was independently associated only with hypertension. Considering children who met criteria for pre-hypertension and hypertension after first screening McNiece et al. emphasized that $20 \%$ of children after first screening could be considered to be "at risk " for them the lifestyle modifications and more frequent monitoring would be crucial ${ }^{17}$. Such approach would be required for $39.2 \%$ of children in our study. Costanzi et al. demonstrated prevalence rate of high normal BP among children aged 7 to 12 years of $5.4 \%$ and elevated BP of $8.4 \%$ after first screening. Overweight was $28.1 \%$ of participants and high BP was more frequent among those ${ }^{26}$. Stephen et al. indicated that familial influence could be detected in children and it is possible that factors responsible for essential hypertension are acquired in childhood ${ }^{27}$. Alpay et al. demonstrated, using ambulatory BP monitoring and Task Force criteria for hypertension, the presence and impact of parental hypertension in children aged $3-18$ years. Children with a positive family history of hypertension had beside higher weight and BMI values, early changes in BP parameters, compared with children with normal BP. Those findings suggest that children with positive family history of hypertension are at increased risk for hypertension in later life and deserve closer evaluation and follow-up ${ }^{28}$. In our study, the prevalence of positive family history of hypertension was present in $51.4 \%$ of girls and $42.3 \%$ of boys with elevated BP and 43.35 of girls and $35.2 \%$ of boys with high normal BP. But also $44.5 \%$ of girls and $34.1 \%$ of boys with normal $\mathrm{BP}$ with positive family history of hypertension could be considered to be »at risk «. Malbora et al. have reported rate of $1.4 \%$ of children (average age 14.02 \pm 1.88 ) in a sample of 2776 children with at least one hypertensive relative revealed by questionnaire. The history of hypertension was the highest in grandmothers. The SBP and DBP levels of children with positive family history of hypertension measured by 24-hour ambulatory blood pressure monitoring $(\mathrm{ABPM})$ were significantly higher than in those without family history of hypertension ${ }^{29}$. Munger et al. found higher mean of SBP at the first screening compared to children without such a history ${ }^{30}$. We found the similar results in our study in girls (114.78 vs. 113.30 $\mathrm{mmHg}$ ) and in boys (117.14 vrs. $116.28 \mathrm{mmHg}$ ). The mean of DBP in our study were also higher among girls (68.57 vrs $67.47 \mathrm{mmHg}$ ) and boys $(69.69$ vs. $68.41 \mathrm{mmHg})$ with positive family history of hypertension. Salvadori et al. have found prevalence of pre-hypertension in cross sectional study in $7.6 \%$ and hypertension in $7.4 \%$ of children aged 4-17 years, after first screening. The difference in prevalence rate of overweight and obesity could be explained by use of different criteria as well as for hypertension. Overweight and obesity was present in $18.1 \%$ and $11.4 \%$ of children, respectively. The criteria used to determine pre-hypertension were those recommended by 
Task Force. Only children aged $\geq 12$ year for SBP and $\geq 16$ years for DBP were considered pre-hypertensive if $\mathrm{BP}$ was $\geq 120 / 80 \mathrm{mmHg}$ and it might explain the difference in pre-hypertension prevalence rate. Positive family history of hypertension was reported by $15.1 \%$ participants (in our study $39.7 \%$ ). Data on family history was collected by face to face computer assisted interview and as we did it by questionnaire but such a difference in reported rate could not be explained by different methodology ${ }^{31}$. The questionnaire provides a reliable and valid method of collecting family history and can be used justifiably as a risk factor for life-style related diseases among children and youth $^{32}$. Because of large association between obesity and elevated BP across age group and genders in this study independently of family history of hypertension authors suggest that substantial part of elevated BP in observed rural population could be explained by overweight and obesity ${ }^{31}$. The high prevalence of pre-hypertension and hypertension in our study could indicate the very high presence of CVR in population according to high rate of reported positive family history of hypertension. Mavrakanas et al. determined prevalence of elevated BP in rural Greek population of 4-10 years children $7.9 \%$ after firs screening. Obesity was associated with and increased risk of elevated BP (relative risk of 5.2 to 6.2) independently on criteria used. The criteria used to determine overweight and obesity were CDC growth charts, IOTF standards and national referent values. The prevalence of obesity varied from $13.6 \%$ to $31.7 \%$ for boys and from $14.4 \%$ to $35.1 \%$ for girls. The study was performed as a part of compulsory school health screening program. Those programs are approved and organize by Ministries of Health and Education and are exempt from additional ethics committee. Throughout regular systematic examinations could reveal actual CVRs and follow up the children considered to be "at risk «. Elevated BP was determined as $\mathrm{BP} \geq 95^{\text {th }}$ percentile using normative Greek charts according to age, gender and height. Authors' suggestion regarding explanation of high prevalence of obesity in rural areas is lack of health education and general perception in rural areas to be overweight is a sign of good health $^{33}$. Similar general opinion seemed to present in Croatia, despite the prevalence rate of overweight and obesity is lower than presented in this study. Antal et al. reported prevalence of elevated $\mathrm{BP}$ among 6345 school children in Hungary aged 15 to 18 years, $14.1 \%$ in boys and $2.5 \%$ in girls after first recordings. The criteria of hypertension were $\mathrm{SBP} \geq 135$ and/or $\mathrm{DBP} \geq 85 \mathrm{mmHg}$ for age group 15 years and $\mathrm{SBP} \geq 140$ and/or $\mathrm{DBP} \geq 90 \mathrm{mmHg}$ for those aged $>15$ years. After three BP measurement in three separate occasions the prevalence rate among boys was $7.5 \%$ and in girls $1.1 \%$. More hypertensive were found among the obese than non-obese subjects. Hypertensive children were referred to further examination or treated by school doctors. A portion of hypertensive students were not aware of pathological BP values and consequences $^{34}$. Urrutia-Rojas et al have reported prevalence of $20.6 \%$ of hypertension ( $\geq 95^{\text {th }}$ percentile) after first screening using oscillometric method, among school children aged 10-12 years. The factors associated with high BP in this study were obesity and ethnicity. Likelihood of having high BP was at least three times higher among overweight children ( $\geq 85^{\text {th }}$ percentile). In this study, females showed higher risk of $\mathrm{BP}>95$ percentile than males. The prevalence of systolic hypertension was $16 \%$ and diastolic $2 \%^{35}$. Dinç et al. reported prevalence rate of pre-hypertension 14\%, hypertension of $3.5 \%$ (after first screening) which might have been attributed to low prevalence of overweight and obesity. The school based survey was conducted among 1346 adolescents aged 15-18 years; Task Force criteria for BP and CDC for overweight/obesity were used. Family history of hypertension was reported by $22 \%$ of participants. Systolic hypertension was found in $2.5 \%$ and diastolic in $1.8 \%$. The prevalence of pre-hypertension/hypertension was the highest among children aged 15 years old $25.5 \%$ with higher prevalence in females. These results are the similar to our findings and might indicate that in this age group of 14-15 years old adolescents the level of CVR is high, especially pre-hypertension. In this study as pre-hypertensive were considered just those children with $\mathrm{SBP}$ and/or DBP $\geq 90^{\text {th }}$ percentile ${ }^{36}$. Čavlek et al. have found among children in $8^{\text {th }}$ of primary school prevalence of elevated BP after first screening 4.4\% (in girls $2.7 \%$ and in boys $6.1 \%$ ) using the criteria SBP and/or DBP $\geq 140 / 90 \mathrm{mmHg}$. Average values of SBP, DBP and BMI were higher in group of children with elevated BP. Elevated SBP was found in $0.7 \%$ girls and $3.9 \%$ boys, elevated $\mathrm{DBP}$ was found in $0.7 \%$ girls and was not found in boys. Elevated SBP and DBP were found in $1.3 \%$ girls and $2.2 \%$ boys. Positive family history of CVR was found in $29.6 \%$, positive personal history on CVR was found in $37 \%$ and overweight was present in $29.6 \%$ children. Considering the number of CVR factors in all participants (2350 in $5^{\text {th }}$ and $8^{\text {th }}$ grade of primary school and $1^{\text {st }}$ grade of secondary school), elevated BP without associated risks was present in $9 \%$ of participants and $60.4 \%$ of participants had 2 or more CVR factors. As in our study, this study presented high CVR among children in Croatia ${ }^{37}$. Rumboldt et al. have found among subgroup of children, considered as at risk, whose parents have suffered a heart attack in their late thirties and early forties that relative weight, $\mathrm{BP}$ and plasma cholesterol were significantly higher. Elevated BP (>124/84 $\mathrm{mmHg}$ ) was found in $40 \%$ of those children. In $36 \%$ of children the most prevalent risk factors were overweight and elevated $\mathrm{BP}^{38}$. Positive personal and family history on thyroid gland disease and it influence was not discussed in recent BP screening studies. Our results suggest that it might have influence in girls with elevated BP, but not in those with high normal. However, results of our study indicates high rate of CVR in population of children aged 14-15 years and support the idea that is a age of 12 to 14 a possible critical temporal window for short term monitoring of $\mathrm{BP}$ and possibly to its maintenance up to the adult life ${ }^{39}$. Some of the limitations of our study are that BP measurement was performed during only one visit to school, since it may overestimate the prevalence of high normal and elevated BP. The second limitation could be the method of categorisation of family members as hyperten- 
sive according to information obtained by questionnaire. Blood pressures of parents and other relatives were not measured and medical records were not used for validation of data from family and personal medical history. As Brady et al. emphasized, to prevent the long-term complications of unrecognized or untreated hypertension, it is important for health care providers, especially pediatricians and school medicine specialists to recognize children with elevated BP as early as possible. Once elevated $\mathrm{BP}$ is recognized, confirmation, evaluation, and treatment can commence. Enhanced provider education is needed to ensure that providers are practicing in the context of current guidelines and to improve ability to detect elevated BP in children who may seem to be at low risk ${ }^{23}$. The results of our study indicates inconsistency of findings considering classification of children in BP categories: normal, high-normal and elevated BP. Observation of associated common CVR factors indicates that presence of associated CVR factors such as personal medical history and family history of CVR is more frequent in children with elevated $\mathrm{BP}$ in comparison with those with normal BP. This trend was not observed in our study in children with high normal BP. But, as it was previously emphasized, the progression from pre-hypertension to hypertension requires further examination and follow up of children at risk group, those who met criteria for adult elevated BP (greater than or equal to $120 / 80 \mathrm{mmHg}$ ) in order to prevent development of cardiovascular disease in the future. School medicine in Croatia could detect children in risk for CVR and develop the data base of common CVR throughout regular program of specific preventive measures. The associated factors such as overweight, family history of hypertension and personal history of thyroid gland (in females) observed in this study can be used as independent markers of having elevated BP. Population of school aged children may be followed-up throughout school age, resulting in implementation of databases with the purpose of revealing the CVR thus making it possible to take useful measures, trying to prevent diseases and promote healthy life style.

\section{R E F E R E N C E S}

1. GILES TD, BERK BC, BLACK HR, J Clin Hypertens, 7 (2005) 505 - 2. POULTER N, Heart, 89 Suppl 2 (2003) 2. - 3. KEARNEY PM, WHELTON M, REYNOLDS K, MUNTNER P, WHELTON PK, HE J, Lancet, 365 (2005) 217. - 4. MURRAY CJ, LOPEZ AD, Lancet, 349 (1997) 1269. - 5. ERCEG M, KERN J, BABIĆ-ERCEG A, IVICEVIĆ-UHERNIK A, VULETIĆ S, Coll Antropol, 33 Suppl 1(2009) 19. — 6. SOROF JM, LAI D, Pediatrics, 113 (2004) 475. - 7. CHIOLERO A, CACHAT F, BURNIER M, PACCAUD F, BOVET P, J Hypertens, 25 (2007) 2209. - 8. NATIONAL HIGH BLOOD PRESSURE EDUCATION PROGRAM WORKING GROUP ON HIGH BLOOD PRESSURE IN CHILDREN AND ADOLESCENTS, Pediatrics, 114 Suppl 2 (2004) 555. - 9. CHOBANIAN AV, BAK RIS GL, BLACK HR, CUSHMAN WC, GREEN LA, IZZO JL JR, JONES DW, MATERSON BJ, OPARIL S, WRIGHT JT JR, ROCCELLA EJ, JAMA, 289 (2003) 2560. - 10. BAO W, THREEFOOT SA, SRINIVASAN SR, BERENSON GS, Am J Hypertens, 8 (1995) 657. — 11. LAUER RM CLARKE WR, Pediatrics, 84 (1989) 633. — 12. MAHONEY LT, CLARKE WR, BURNS TL, LAUER RM, Am J Hypertens, 4 (1991) 608. — 13 SHEAR CL, BURKE GL, FREEDMAN DS, BERENSON GS, Pediatrics, 77 (1986) 862. - 14. PRINEAS RJ, GILLUM RF, HORIBE H, HANNAN PJ, Hypertension, 2 (1980) I24. - 15. MUNTNER P, HE J, CUTLER JA WILDMAN RP, WHELTON PK, JAMA, 291 (2004) 2107. — 16. FALKNER B, GIDDING SS, PORTMAN R, ROSNER B, Pediatrics, 122 (2008) 238. - 17. MCNIECE KL, POFFENBARGER TS, TURNER JL, FRAN CO KD, SOROF JM, PORTMAN RJ, J Pediatr, 150 (2007) 640. — 18. GENOVESI S, GIUSSANI M, PIERUZZI F, VIGORITA F, ARCOVIO C, CAVUTO S, STELLA A, J Hypertens, 23 (2005) 493. — 19. BÉLAND Y, BAILIE L, PAGE J, A joint effort in implementing the 2003 Croatian Adult Health Survey. In: Proceedings (Statistics Canada, Croatian Ministry of Health and Central Bureau of Statistics, American Statistical Association Meeting, Survey Research Methods-Toronto, Canada 2004). - 20. JUREŠA V, MUSIL V, KUJUNDŽIĆ-TILJAK M, Coll Antropol, 36 Suppl 1. (2012) 47. — 21. JUREŠA V, MUSIL V, MAJER M, IVANKOVIĆ D, PE-
TROVIĆ D, Coll Antropol, 36 Suppl 1. (2012) 139. - 22. JUREŠA V, MUSIL V, KUJUNDŽIĆ TILJAK M, Hrvatske referentne vrijednosti tjelesne mase, tjelesne visine i indeksa tjelesne mase kod dječaka i djevojčica $u$ dobi od 6, 5 do 18, 5 godina, 2009, accessed 14.06.2011. Available from: URL: http://www. mef.hr/ druga.php?grupa $=020332050100$. -23 . BRADY TM, SOLOMON BS, NEU AM, SIBERRY GK, PAREKH RS, Pediatrics, 125 (2010) 1286. - 24. AKGUN C, DOGAN M, AKBAYRAM S, TUNCER O, PEKER E, TASKIN G, ARSLAN S, ARSLAN D, Nippon Med Sch, 77 (2010) 160 - 25. ADROGUE HE, SINAIKO AR, Am J Hypertens, 14 (2001) 412. - 26. COSTANZI CB, HALPERN R, RECH RR, BERGMANN ML, ALLI LR, MATTOS AP, J Pediatr (Rio J), 85 (2009) 335. — 27. ZINNERSH, LEVY PS, KASS EH, N Eng J Med, 284 (1971) 401. - 28. ALPAY H, OZDEMIR N, WÜHL E, TOPUZOGLU A, Pediatr Nephrol, 24 (2009) 155. - 29. MALBORA B, BASKIN E, BAYRAKCI US, AGRAS PI, CENGIZ N, HABERAL M, Renal Failure, 32 (2010) 535. - 30. MUNGER RG, PRINEAS RJ, GOMEZ-MARIN O, Jour of Hypert, 6 (1988), $20-31$. SALVADORI M, SONTROP JM, GARG AX, TRUONG J, SURI RS, MAHMUD FH, MACNAB JJ, CLARK WF, Pediatrics, 122 (2008) 821. - 32. SAITO T, NANRI S, SAITO I, Pediatrics Int, 51 (2009) 514. - 33. MAVRAKANAS TA, KONSOULA G, PATSONIS I, MERKOURIS BP, Rural Remote Health, 9 (2009) 1150. - 34. ANTAL M, REGOLY-MEREI A, NAGY K, GREINER E, BIRO L, DOMONKOS A, BALAJTI A, SZORAD I, SZABO C, MOZSARY E, Ann Nutr Metab, 48 (2004) 307. — 35. URRUTIA-ROJAS X, EGBUCHUNAM CU, BAE S, MENCHACA J, BAYONA M, RIVERS PA, SINGH KP, BMC Pediatrics, 6 (2006) 32. - 36. DINÇ G, SAATLI G, BAYDUR H, OZCAN C, Anadolu Kardiyol Derg, 9 (2009) 450. - 37. CAVLEK T, MANDAC V, PERKOVIĆ N, GRŚIC K, Paediatr Croat, 46 (2002) 163. - 38. RUMBOLDT M, RUMBOLDT Z, PESENTI S, Coll Antropol, 27 (2003) 221. - 39. MAGGISANO V, CHIAROTTI F, BOTUNAC I, CAMPANELLA C, GALIETTA G, LOIZZO A, Am J Epidemiol, 20 (2005) 517.

\section{Jureša}

University of Zagreb, School of Medicine, »Andrija Štampar « School of Public Health, Rockefeller Street 4, 10000 Zagreb, Croatia

e-mail:vjuresa@snz.hr 


\section{UČESTALOST I PRIDRUŽENI ČIMBENICI RIZIKA ZA POVIŠENI ARTERIJSKI TLAK U ŠKOLSKE DJECE I MLADIH}

\section{S A Ž E T A K}

Povišeni arterijski tlak u djece i mladih određuje se na temelju normalne distribucije izmjerenog arterijskog tlaka u zdrave djece. Cilj ovog istraživanja bio je utvrditi učestalost visokog normalnog i povišenog arterijskog tlaka u zdrave školske djece, obzirom na prisutnost ostalih kardiovaskularnih rizika. Istraživanje je provedeno među 965 (48,7\% djevojčica) učenika 8. razreda osnovnih škola. Podaci za potrebe ovog rada prikupljeni su pomoću upitnika i antropometrijskim mjerenjima. Učestalost visokog normalnog iznosila je u djevojčica $28,5 \%$, u dječaka $36,8 \%$, dok je učestalost povišenog arterijskog tlaka iznosila u djevojčica 7,9\% i 5,3\% u dječaka. Prekomjernu tjelesnu težinu imalo je 19,4\% djevojčica i $9,3 \%$ dječaka s visokim normalnim i $29,7 \%$ djevojčica i $30,8 \%$ dječaka s povišenim arterijskim tlakom. Najčešći pridruženi kardiovaskularni rizik bila je hipertenzija u obiteljskoj anamnezi. Otkrivanje i praćenje čimbenika kardiovaskularnih rizika moguće je u školskoj dobi kroz aktivnosti školske medicine, s ciljem poduzimanja preventivnih mjera $\mathrm{i}$ promicanja zdravog načina života. 